\title{
Private actor accountability on international regimes
}

\section{Akuntabilitas aktor privat dalam rezim internasional}

\author{
Wahyudi Purnomo ${ }^{1}$, Novita Putri Rudiany ${ }^{2}$, Citra Hennida ${ }^{1}$ \\ ${ }^{1}$ Department of International Relations, Universitas Airlangga, Surabaya \\ Jalan Dharmawangsa Dalam, Surabaya 60286 \\ ${ }^{2}$ University of Groningen majoring at International Relations \\ and International Organization \\ E-mail: wpur56@gmail.com,novitarudiany@gmail.com, citra.hennida@fisip.unair.ac.id
}

\begin{abstract}
Public-Private Partnerships (PPPs) have emerged along with the growing role of corporations in global development. One of the largest forms of PPP today is the UN Global Compact. The UN Global Compact involves of companies, NGOs, IGOs and state governments. All of them are trying to realize globalization with a more humanist face with attention to the protection of human rights, environment, labor standards and anticorruption. Engaging private actors in global governance, The UN Global Compact raises many issues such as power, authority, and legitimacy. The effort to tackle it all is to increase PPP accountability. This research seeks to describe what efforts can be made to enhance private accountability within the international regime. The research undertaken is a descriptive study, focuses on public-private partnerships in the UN Global Compact regime. The study found that there were two attempts that could be done. First, by involving the stakeholders in the development of procedures, mechanisms, reporting and monitoring associated with trying to improve the company's reputation. Second, by looking at corporate relations as agent and UN Global Compact as principal in principal-agent relation in the international regime.
\end{abstract}

Keywords: public-private partnership, international regime, UN Global Compact

\begin{abstract}
Abstrak
Kerja sama antara publik dan privat banyak mengemuka seiring dengan semakin besarnya peran korporasi dalam pembangunan global. Salah satu bentuk PPP terbesar saat ini adalah UN Global Compact. UN Global Compact beranggotakan perusahaan, NGO, IGO dan pemerintah negara. Mereka bersama-sama berusaha mewujudkan globalisasi dengan wajah yang lebih humanis dengan memperhatikan perlindungan HAM, perlindungan lingkungan, standar labor dan anti-korupsi. Melibatkan aktor privat dalam tata kelola global memunculkan banyak masalah seperti power, otoritas, dan legitimasi. Upaya untuk menanggulangi itu semua adalah dengan meningkatkan akuntabilitas PPP. Riset ini berusaha mendeskripsikan apa saja upaya yang bisa dilakukan untuk meningkatkan akuntabilitas privat dalam rezim internasional. Penelitian ini merupakan penelitian deskriptif, berfokus pada kerjasama publik dan privat dalam rezim UN Global Compact. Penelitian menemukan bahwa ada dua upaya yang bisa dilakukan. Pertama, melibatkan stakeholders dalam pengembangan prosedur, mekanisme, pelaporan dan monitoring yang dikaitkan dengan upaya peningkatan reputasi perusahaan. Kedua, meningkatkan akuntabilitas dengan melihat relasi perusahaan sebagai agent dan UN Global Compact sebagai principal dalam hubungan principal-agent dalam rezim internasional.
\end{abstract}

Kata kunci: kemitraan publik-swasta, rezim internasional, UN Global Compact

\section{Introduction}

Public-Private Partnership (PPP) has emerged in the era of globalization. The increased involvement of cooperation is driven by the difficulties to provide public goods due to the limited budget of the government. On the other hand, the number of transnational corporations are increasing and directly affecting the global economy. These companies can gain large revenue, which is sometimes bigger than the national income of a country. This condition could not be separated from the fact that the trend of Foreign Direct Investment (FDI) is also increasing. FDI has increased fourfold, from 1.7 million dollars in 1990 to 6.6 million dollars in 2001. In this case, the presence of transnational corporations gives a positive impact of technology innovation and management. Despite, there are some skeptical groups who reject the presence of transnational corporations, called anti-corporate groups. Anti-corporate activists argued that transnational corporations caused economic gaps. The rejection of the presence 
of multinational corporations was demonstrated in the 1970s. Many developing countries opposed to foreign investment. Developing country governments assumed that transnational corporations only utilized the state resources, without making much of a reward. As a result, many governments in developing countries imposed restrictions and requirements on transnational corporations related to technology transfer, domestic participation, local content and some other aspects.

Entering the era of globalization, skeptical perceptions of transnational corporations began to change. FDI was later considered to be beneficial, and some developing countries which applied strict regulations began to change and started to have an orientation of attracting foreign investment into the country (Koenig-Archibugi 2005). Therefore, intergovernmental cooperation, business arrangements and initiatives involving non-governmental organizations and supranational institutions are required in setting standards of conduct for companies and monitoring corporate compliance with those rules (Koenig-Archibugi 2005). The attempts to regulate corporate behavior have been done in several international regimes. Some of the examples are Agenda 21 which calls the action from governments, companies and civil society to address human impacts on society. There is also Beijing Declaration, as an international declaration on the rights of women. CERES principles which consist of ten point codes of corporate environmental conduct to be used as an environmental mission statement or ethics. OECD guidelines for multinational enterprises. Global Reporting Initiative as a framework for reporting on social, environmental and economic performance, as well as the principles of responsible investment and Wolfsburg anti money laundering principles.

The last effort is on UN Global Compact. The UN Global Compact aims to bring together companies, civil groups, trade unions, environmental activists, NGOs and the UN (ILO, UNDP, UNEP, OHCHR, UNIDO, UNODC) to adopt, support and realize basic human rights principles, employment, environment, and anti-corruption (Therien \& Pouliot 2006). These activities are actually based on the voluntary principal. The idea of UN Global Compact is to manage the involved private sector since it has some problems. Managing private involvement in global governance is difficult because the shareholders and market's interests dominate it (Hoessle 2013, Threin \& Pouliot 2006). Arevalo \& Fallon (2008) added the difficulty of involvement of private actors in authority. To this end, the authority refers to the states or IGOs in global governance. Besides, the legitimacy has become another difficult matter.

From the problems raised above, it raises the question of what efforts can be made to increase private accountability in the international regime. Taking the case at the UN Global Compact, we argue that there are two possible efforts to increase private accountability. First, involving the stakeholders in the development of procedures, mechanisms, reporting and monitoring associated with improving the company's reputation. Second, looking at corporate relations as agent and UN Global Compact as principal in principal-agent relation in the international regime.

\section{Research Method}

The research undertaken is a descriptive study describing how to improve the accountability of corporates within the international regime. To limit the discussion, this study focuses on public-private partnerships in the UN Global Compact regime. This regime was chosen because it is the largest public and private initiative for now. The UN Global Compact includes companies, trade unions, civil society, NGOs, and UN agencies such as ILO, UNDP, UNEP, OHCHR, UNIDO, UNODC. As of May 2017, there were 9,388 companies, 165 countries, and 45,581 public reports produced by the UN Global Compact. The second reason for the UN Global Compact is that the regime aims to regulate good corporate practices that promote the principles of human rights protection, good labor practices, environmental protection and anti-corruption campaigns. Until now, the efforts to regulate good corporate practices still meet many weaknesses, which serve more needs of the companies than the public needs. The data collected in this research is secondary data. Secondary data is obtained through books, research reports, journals, and articles on the internet. Then, the data were analyzed by applying the qualitative technique which processed and analyzed the collected data 
to be the meaningful, systematic, organized, and structured data to draw conclusions. The qualitative technique is used to support the statement (Sutopo \& Arief 2010).

\section{Result and Discussion}

\section{UN Global Compact as public-private partnership}

PPP is a form of hybrid governance, in which the political authority of non-state actors is recognized. Previously, the role of non-state actors has been much in informal governance, for example became lobbyist and observers. With the PPP, the role of non-state actors has formally recognized as well as the state's role in global governance. PPP contributes in agenda setting, policy formulation, corporate social responsibility, environmental protection, human rights protection, labor standards, anticorruption, humanitarian assistance, etc. (Bull \& McNeill 2006:6). PPP might be a non-binding -as it is said before in the previous section- or a binding cooperation. The moment of PPP is considered as the binding form is when there is a preliminary contract for a particular project. The UN Global Compact by definition is a form of PPP because its members include state and non-state actors. In addition, there is a share of risk, responsibility, resources, competence and other benefits on the UN Global Compact (Nelson 2001:46). In addition, the World Bank defines PPP as a commitment of members to share resources (financial, technical or personal) on agreed activities along with the clear division of tasks and accountability in accounting for those activities (Tesner 2000:71).

Kofi Annan first introduced the UN Global Compact at the Davos World Economic Forum in 1999. Kofi Annan called for the company's active involvement in the global development and made globalization became fair for all. Therefore, the UN Global Compact is the largest corporate initiative. The UN Global Compact is a global version of corporate social responsibility focusing on the dissemination of corporate norms and best practices in the principles of human rights, labor, environment and anti-corruption (Ruggie 2003). The birth of UN Global Compact was influenced by several things. First, Globalization is the main factor. Globalization accelerates the movement of goods, services and people. It pushes firms to produce their product globally in order to see efficiency. In the post Fordism era, MNCs run into the global value chain. Therefore, as far as their operation reaches worldwide, firms should also take responsibility in their operation. The second is the increasing power of business corporations' influence. The third is growing access to education and information. While the fourth is growing awareness of environmental issues. And the fifth is the spread of corporate scandals and public distrust.

There are two main goals of the UN Global Compact. First, bringing private companies together with UN agencies to adopt, support and realize basic principles in human rights, labor, environmental, and anti-corruption standards (Therien \& Pouliot 2006). The second objective of the UN Global Compact is to facilitate cooperation between various economic and social actors in the global arena to promote UN values. Thus, in addition to the private sector, six UN specialized agencies - such as the ILO, UNDP, OHCHR, UNIDO, UNODC - plus government and NGO organizations, are also involved in dialogue and action to promote and develop social responsibility, and encourage partnerships only among these agencies. To achieve this goal, the UN Global Compact offers the facility in several ways, from policy dialogue, training, cooperation between countries or regions, to joint projects (Therien \& Pouliot 2006).

The UN Global Compact contains 10 principles in the protection of human rights, workers, the environment and transparency. These principles are extracted from commitments agreed upon by the government of the United Nations, the Universal Declaration of Human Rights (1948); the Rio Declaration on Environment and Development (1992); the International Labor Organization's Fundamental Principles and Rights at Work (1998); and the UN Convention Against Corruption (2003). The ten principles that business should do are: (1) supporting and respecting the protection of the internationally proclaimed human rights within their sphere of influence; (2) making sure that they are not complicit in human rights abuses; (3) upholding the freedom of association and the 
effective recognition of the right to collective bargaining; (4) the elimination of all forms of forced and compulsory labor; (5) the effective abolition of child labor; (6) elimination of discrimination in respect of employment and occupation; (7) supporting a precautionary approach to environmental challenges; (8) undertaking initiatives to promote greater environmental responsibility; (9) encouraging the development and diffusion of environmentally friendly technologies; (10) working against corruption in all its forms including extortion and bribery.

UN Global Compact was designed as voluntarily initiative. The UN Global Compact provides rules and procedures for businesses to keep their actions in accordance with the ten principles of the Global Compact. The Communication on Progress (COP) is the main thing that shows the company's commitment to engage in the UN Global Compact. Through its website, COP shows the reporting and transparency process that has been done by the company. Failure to submit the report within two years will result in participants' list of participants. For companies from OECD countries, the COP is collected maximum one year after they are incorporated in the UN Global Compact. While for companies coming from non-OECD countries, the submission of COP is not later than three years after they join.

\section{Accountability on the UN Global Compact}

Eventhough this idea was designed based on voluntary action, the UN Global Compact should pay attention to the action of the corporations within it. It is because the need of concrete action should be implemented by the corporation under the supervision of the UN. Giving one example is the case of Bayer AG. It has been known that Bayer is a large pharmaceutical company, based in Germany. Bayer AG claimed itself as one of the founding members of UN Global Compact, supporting the idea of UN Secretary, Kofi Annan. However in 2002, Bayer AG was listed as the ten worst corporation of 2001 by the Washington DC-based Multinational Monitor magazine due to some paradoxes of their commitments within UN Global Compact. Some of the issues are selling antibiotics with a very high price to the American Government, as well as withdrawing the cholesterol-reducing drug, called Lipobay or Baycol which caused 100 people died (Mimkes 2002). These events were not as popular as the announcement that Bayer gave medicine support for victims of the earthquake in India and El Salvador, also gave donation to the NGOs which directly handled the situation after the tragedy of $9 / 11$ in the U.S. In the other words, the corporation tends to disclose their positive activities and ignored their scandals. Therefore, it is important to have a deep study on preventing this kind of situation and stressing on the accountability of the corporation for years ahead.

As a public-private partnership, the UN Global Compact has three problems regarding the participation of the private sector in global governance. There are problems with power, authority and legitimacy. The requirement of being legitimized for the institutions is providing the procedural logic. The institutions become legitimate because they exist and operate on mutually agreed terms. Legitimacy can also be based on the logic of consequences. Institutions can be legitimized when it contributes to solving the problems within the stipulated areas of work. As consequence, the cooperation model should be contractual and transparent. There is a correlated relationship based on members' compliance with contract specifications (Lloyd 2008). The stakeholder's interests should be represented in decision-making. The accountable decision is a conclusion that must be trusted by the actors affected by the decision (Held \& Koenig-Archibugi 2005). For that reason, the rules in its establishment should be inclusive by involving the parties which will be affected by the rules. Dingwerth (2007:38) argues that inclusiveness can be done in two dimensions: (1) the reach of participation, when all actors involved are formally represented in the decision-making process; (2) the quality of participation, when the actors involved have equal opportunity in participating.

The UN Global Compact does accommodate membership to corporations, NGOs, IGOs and governments; but governments of developing countries have limited representation. NGO participation is limited and the requirements for NGOs are also more rigid than requirements for corporations. On the contrary, the participation of the corporate sector is enormous, even seen as overrepresented in 
terms of its not so great financial contribution (Buse \& Harmer 2007, Therien \& Pouliot 2006).

Williams (2004) adds that there are two categories of critics on the Global Compact's legitimacy. First, the Compact is another code without accountability, a public document without substance. The Compact has lack of an independent monitoring provision. The public will only know about a company according to its report, which is usually "the chosen" issue of the company. Therefore, the Compact's network structure should be designed to enhance corporate learning through "best practices" and other measures; there are no performance standards and verification procedures. Second, the Compact legitimacy has yet to prove itself. This group argues for a mandatory legal framework as the only way to guarantee that companies are accountable to the least advantaged in the global economy.

As the public-private partnership is a multi-sector network model because it involves many sectors, its governance must be accountable. Broadly speaking, there are endogenous and exogenous factors that influence this kind of accountability. On one hand, the endogenous factor is by looking at the internal company. At this level, accountability is embedded with organizational culture. Lloyd, Warren \& Hammer (2008) mention that it is accountability at the "software" level. "Software" refers to the formation of a culture of accountability. Accountability must be integrated into staff attitudes and behaviors. At the "software" level this can be done with the development of incentives and sanctions to encourage staff to adopt behaviors which are appropriate to the desired accountability. Bernstein (2005) adds that the inclusiveness of stakeholders creates a perception of ownership that members will behave in accordance with the norms that have been promoted. Keohane (2006) asserts that internal accountability is accounted for shareholders who have delegated power to the company.

On the other hand, accountability at exogenous levels can be accomplished by developing "hardware" which are procedures, mechanisms and reporting processes (Lloyd 2008). These procedures, mechanisms and reporting processes are accountable to those affected by corporate behavior and activities (Keohane 2006:79). The UN Global Compact procedures, mechanisms and reports are on the company's Communication on Progress (COP) report. Although there is no specific format in the $\mathrm{COP}$, the $\mathrm{COP}$ at least contains a statement from the chief executive to continue to commit to the UN Global Compact, any description that has been made by the company in relation to the 10 principles, and includes a measuring tool for achieving outcomes.

There are three categories in COP. The lowest category is GC Learner where the reported COP has not met the minimum required standard. The second category is GC Active where the reported COP meets the requested standards. The top category is GC Advanced where the reported COP complies as GC Active plus an explanation of the implementation and best practices already performed. This COP is transparent and accessible to all members and other stakeholders. At the same time, COP responds to the demands of transparency from key stakeholders such as investors, community groups, governments and consumers. Companies can communicate about the steps that have been and will be made to support their commitments regarding the issue of human rights, labor standards, environmental protection, and anti-corruption. So that, the public will be able to read it in the company profile, which has not been done much. Besides, the UN Global Compact encourages members to always communicate the principles that exist within the media communications owned by companies such as press releases, speeches, etc. The dialogue process developed within the UN Global Compact will boost the accountability. The networking structure in UN Global Compact collaboration enables communication and dialogue. The process of argumentation and negotiation creates more effective regulation because it builds more towards consensus formation rather than compromise (Risse 2000). COP also shows transparency. Hale \& Mauzerall (2004:226) say that without any transparency, cooperation will only create an illusion of progress where the report cannot be translated into concrete steps. 
Keohane (2006) argues that accountability is needed to strengthen the company's reputation. The UN Global Compact provides a reputation for the company. The values promoted by the UN Global Compact are universal values such as human rights, labor standards, environmental stewardship and the fight against corruption. Sharing that universal value will enhance the company image and strengthen the brand. The UN Global Compact also reduces the negative publicity by many non-state actors. The UN Global Compact links corporations to state and non-state actors such as environmental activists, working groups and human rights based organizations. By doing the activities of engagement and consultation, these actors can avoid the negative publicity of these groups, especially for companies which are operating in countries that have tremendous human rights violations (Potoski \& Prakash 2005). The company's vulnerable position also exists in companies engaged in extractive industries where the host country's interference is very large and prone to corruption (Karl 1997). Here, the UN Global Compact not only helps in improving the negative reputation of non-government actors, but also protects the company from the corrupt behavior of state actors.

Keohane (2006) adds the need for professional accountability or peer accountability in the network. Accountability that is done by people from the same sector; can be from fellow members, expert groups or members of the business community. In addition, external accountability is implemented through "naming and shaming". This is related to the company's reputation in public. UN Global Compact is already doing this but the action needs to be more measurable and real. For example there needs to be a penalty for the behavior of not giving a COP report. The penalty may be a ban on the inclusion of the UN Global Compact logo until the obligation as a member is fulfilled. Otherwise, maximizing "naming and shaming" for low performing companies can also be applied.

In this case, the role of NGOs becomes crucial. NGOs monitor corporate behavior, present data on company violations, engage in public shaming, and encourage consumer pressure on companies. Therefore, the company has a big interest in compliance because the reputation is only obtained if the company becomes sensitive to the public desire. The company will always calculate the profit earned by responding positively to market demands. This is where accountability to the UN Global Compact goes (Koenig-Archibugi 2005, Keohane 2006, Pototski \& Praash 2005, Ruggie 2003, Hurd 2003). In a constructivist view, accountability can be achieved when rules are deemed appropriate to be obeyed. The role of persuasion and socialization of the market becomes crucial (Risse 2000). Ruggie (2003:310) adds that cooperation such as UN Global Compact is not designed as a coercive rule. The UN Global Compact is a joint learning forum that emphasizes policy dialogue and shared best practices. Consequently, social learning has a significant role. Social learning raises a common understanding that the principles of the UN Global Compact can be internalized in enterprise practices that ultimately operationalize the company will reflect the principles that the UN Global Compact desires.

Accountability can also be analyzed by looking at the relations of the principal agent in the international regime. Principal refers to the UN Global Compact, while agents refer to the company as a member of the UN Global Compact. In principal agent relations, principals can influence agent behavior in many ways. First, the principal can influence by doing "screen and select" personnel placed in the international regime. Thus the personnel in the international regime reflect the interests of the principal. Secondly, the principal may be involved by direct monitoring of agent behavior. The principal can apply procedural rules related to "check and balances". That way the agent can monitor the behavior of other agents and report it to the principal. Finally, the principal can design new contracts with personnel in the international regime, reward and incentives, or apply punishment if agent behavior does not reflect principal interests (Kiewiet \& McCubbins 1991).

As the UN Global Compact is voluntary and anyone can join it, Forman \& Segaar (2006) raised the importance of selection of potential candidates. With a clear assessment, the legitimacy of collective action can be increased because in the selection process must contains transparency. Nelson (2001) adds that the unclear corporate reputation could jeopardize the reputation of the United Nations. In the other words, the lack of clarity will have a similar effect as the netting method from the principal. 
Basic criteria that can be used for example include competence, representation, and the willingness to communicate and be consistent in the network. The UN Global Compact conducts "screen and selects" for companies that will participate in the UN Global Compact. The banned industries include industries that produce landmines, nuclear weapons, biological weapons, chemical weapons; businesses that are subject to UN sanctions; businesses that are blacklisted by UN Procurement Office for ethical reasons; and the tobacco industry. Zurn (2000) stresses the need for a mechanism that could increase accountability of participants in the network. This is related to the internal procedures and structures of the actors that must be open to public observation. Internal information such as who is responsible for divisions, voting rules and financing procedures needs to be opened and publicly observable. Edwards (2000) offers certification, self-regulation and codes of conduct to further support transparency within the network.

The "check and balances" process is also conducted in the corridor of the UN Global Compact. "Checks and balances" in the UN Global Compact are conducted through corporate interaction with NGOs. The membership of the UN Global Compact is not only a company but also involves labor unions, environmental activists, NGOs, UN agencies (ILO, UNDP, UNEP, OHCR, UNIDO, UNODC). Together they seek to promote universal values such as human rights, work standards, environmental protection and combating corruption. Activities undertaken in the Global Compact are the processes of consultation and sharing of knowledge in forums initiated by the Global Compact such as the UN Global Compact Leaders' Summit, the UN Private Sector Forum, the UN Forum on Business and Human Rights. These forums along with the COP report are made transparent, as a result the company becomes more cautious and as far as possible apply the 10 principles of the Global Compact. Because of its transparency in COP reporting, for example through websites that can be viewed and accessed by everyone, the process of accountability is done by the public such as media and NGOs. So when there are corporate practices that are perceived to be inconsistent with the UN Global Compact ethical standards, they can be reported. Given this interaction, dialogue and diplomacy actions are more emphasized than confrontation and sanctions (Therien \& Pouliot 2006).

Kiewiet \& McCubbins (1991) emphasize that in principal agent relationships there is the possibility of an "agency slack", when the agent pursues its own interests as a result of the obstacles that the principal undertakes to them. Tamm \& Snidal (2014) differentiate the agency slack into "shirking" when the agent actually minimizes the work done by the principal, and "slippage" when the agent is actively pursuing his own interests which in certain stages even harm and contradict the interests of the principal. Here the criticism that the UN Global Compact is only used by companies as a means of "blue wash" for corporate branding. The UN Global Compact is only used as a means of corporate legitimacy rather than encouraging improved social and environmental circumstances. In this case, the company as an agent, actively pursues the interests of strengthening branding rather than the interests of the UN Global Compact as a principal goal. It was proven in 2004 that less than $60 \%$ of participants took action in accordance with ten agreed principles (Therien \& Pouliot 2006). In addition, many criticisms arise because of the partisanship of the UN Global Compact to aspects of business and transnational corporations. This can be evidenced by more rigid regulations or requirements for NGOs than the corporate sector. Therefore, the UN Global Compact is considered inclined to override the democratic values that will automatically impact the weakening of the system and the position of the UN as a global institution (Therien \& Pouliot 2006). Clapp (1998:300) examines this as a weakness of private sector involvement in global governance. Companies that should be governed by their behavior and at the same time designers of those rules may be pushing only rules that have weak standards to avoid high compliance costs

Agency slack occurs in a common agency with a collective principal or multiple principals because the number of principles provides a higher bargaining position than agents to fight for their interests. However, if the principal has an interest in a particular decision then it will keep monitoring the agent behavior, so that the emergence of agency slack can be reduced (Hennida 2015). There are three levels in the agency slack that are low, medium, and high. Agency slack is said to be high when the number of principals is more than one while the number of agents is single. In this case 
the agent may be difficult to fulfill the desire of the many principals, so that the agendas that are set in the organization are general and the level of independence is high. These general matters aim to accommodate the principal's wishes, since their general nature do not usually clash with principal strategic interests. Therefore, the occurred agency slack tends to be high. Agency slack is said to exist at the middle level when the there are only a single agent and single principal. Here the only options available are either at the agent or principal level. Both agent and principal then do not have many options so the trend is more to do accommodation. Agency slack are seen as a medium as well as many and many principal agents. In this case, the opportunity to get principal and agent as much, so that each of them will get a lot of choices. Agency agency conditions that are too high or too low will make the agent and principal easy to move. Finally, the agency slack is said to be low when the number of many agents is only one principal. The regime may not produce many binding and non-touching rules on the strategic interests of the principal. Otherwise, the possibility is the agent becomes very dependent on principal, principal use agent merely as a tool of importance.

Difficulties faced by the principal in the principal agent relationship. First, the agent may be hiding the information because it could be harmful information agent but assist principal. Second, the agent can take action without the knowledge of the principal, cancel an action if the principal knows it could be a principal will impose sanctions to the agent. Third, Madison's dilemma in which the provision of power to the agent may be used by agents to counter principals (Kiewiet \& McCubbins 1991). Tamm \& Snidal (2014) see problems in principal agent relations as the emergence of adverse selection and moral hazard cases. Adverse selection arises when the agent deliberately does not demonstrate its capability and preferences over a particular case in the hope that the principal can engage more with the organization. Adverse selection may be a form of defiance of what the principal instructs the agent. Some argue that global compact as a political concordance to multinational companies' criticism. They use Global Compact as an effort to protect the multinational company's brand and the Global Compact function as a "blue wash" for corporate branding. The Global Compact was criticized for enhancing the image and legitimacy of the big business, rather than enforcing social and environmental standards. Moreover, the Compact can expel members for monitoring and verification features.

In the principal agent relation, the resulting governance forms are not single. Tamm \& Snidal (2014) identify there are four forms of governance in principal agent relationships: hierarchy, delegation, collaboration, and orchestration. In the delegation and orchestration both involve a third party as an intermediary to target the previously targeted actor. These third parties can be INGOs, business organizations, public and private partnerships, intergovernmental networks and other international organizations. Targeted actors can be countries and companies where international regimes have traditionally not been allowed to govern them. On delegates used hardware such as rules and resolutions. While in the orchestration of this formal rule does not exist and the involvement is based on voluntary. The Global Compact is an orchestration where formal rules do not exist and member involvement is voluntary. Members are only required to provide an annual report (COP) of a nonbinding format.

\section{Conclusion}

Public-private partnerships have emerged with the growing role of corporations in development. One of the largest forms of PPP today is the UN Global Compact. The UN Global Compact consists of companies, NGOs, IGOs and state governments. Together trying to realize globalization with a more humanist face with attention to the protection of human rights, environmental protection, labor standards and anti-corruption. As of May 2017, there were 9,388 companies, 165 countries, and 45,581 public reports produced by the UN Global Compact. Engaging private actors in global governance raises many issues such as power, authority, and legitimacy. The effort to tackle it all is to increase PPP accountability. This research seeks to describe what efforts can be made to enhance private accountability in the international regime. 
The study found that there were two attempts that could be taken. First, it involves stakeholders in the development of procedures, mechanisms, reporting and monitoring associated with improving the company's reputation. The UN Global Compact procedures, mechanisms and reports are on the company's Communication on Progress (COP) report. This COP is transparent and accessible to all members and other stakeholders. COP at the same time responds to the demands of transparency from key stakeholders such as investors, community groups, governments and consumers. The more transparent the company at its COP this will increase the company's reputation in front of stakeholders because the UN Global Compact is a guarantee of the protection of the universal values undertaken by the company. In addition, UN Global Compact also reduces the excess of negative publication because there are dialogue mechanism and social learning between companies and other stakeholders, especially NGOs and the media which has been giving a lot of negative publications to the company's activities.

Second, by looking at corporate relations as agent and UN Global Compact as principal. In principal agent relations, principals can influence agent behavior in two ways. The first through "screen and select" is done transparently and the companies that enter into the members really reflect the interests of the principal. With a clear assessment, the legitimacy of collective action can be improved. Second through the check and balances procedure is done so that the agent can monitor the behavior of other agents and report it to the principal. Other agencies such as NGOs and IGOs can monitor company behavior and report to the principal (UN Global Compact). This monitoring system is necessary for companies to be more careful and to apply the ten principles of the UN Global Compact as much as possible.

\section{References}

Arevalo JA \& Fallon FT (2008) Assesing corporate responsibility as a contribution to global governance: The case of the UN Global Compact. Corporate Governance, 8:456-470.

Bernstein S (2005) Legitimacy in global environmental governance. Journal of International law and International Relations, 1:139-166.

Bull B \& McNeil D (2006) Development Issues in Global Governance: Public-Private Partnership and Market Multilateralism. Warwick Studies in globalization. Routledge: London.

Buse K \& Harmer AM (2007) Seven habits of highly effective global public-private health partnership: Practice and potential. Social Science \& Medicine, 64:259-271.

Clapp J (1998) The privatization of global environmental governance: ISO 14000 and the developing world. Global Governance, 4:295-316.

Dingwerth K (2007) The New Transnationalism: Transnational Governance and Democratic Legitimacy. Houndmills, Bsingstoke: Palgrave Macmillan.

Edwards M (2000) NGO Rights and Responsibilities: A New Deal for Global Governance. London: The Foreign Policy Centre.

Forman S \& Segaar D (2006) New coalitions for global governance: The changing dynamics of multilateralism. Global Governance, 12 (2):205-225.

Hale TN \& Mauzerall DL (2004) Thinking globally and acting locally: Can the johannesburg partnerships coordinate action on sustainable development?. Journal of Environment and Development, 13:220-239.

Held D \& Koenig-Archibugi M (eds) (2005) Global Governance and Public Accountability. Oxford: Blackwell Publishing.

Hennida C (2015) Rezim dan Organisasi Internasional: Interaksi Negara, Kedaulatan, dan Institusi Multilateral. Malang: Intrans Publishing.

Hoessle U (2013) The contribution of the UN Global Compact towards the compliance of international regimes: A comparative study of businesses from the USA, Mozambique, United Arab Emirates and Germany. The Journal of Corporate Citizenship, 53 (2):27-60.

Hurd I (2003) Labor standards through international organizations: The global compact in comparative perspective. Journal of Corporate Citizenship, 11:99-111.

Karl T (1997) The Paradox of Plenty: Oil Booms and Petro-states. Berkeley: University of California 
Press.

Keohane RO (2006) Accountability in world politics. Scandinavian Political Studies, 29:75-87.

Kiewiet R \& McCubbins M (1991) The Logic of Delegation: Congressional Parties and the Appropriations Process. Chicago: University of Chicago Press.

Koenig-Archibugi M (2005) Transnational Corporations and Public Accountability. In: D Held \& M Koenig-Archibugi (eds). Global Governance and Public Accountability. Oxford: Blackwell Publishing.

Lloyd RSW \& Hammer M (2008) 2008 Global Accountability Report. London: One World Trust.

Mimkes P (2002) Bayer and the UN Global Compact: How and Why a Major Pharmeaceutical and Chemical Company "Blewashes" its Image. Corp Watch, 19 July 2002. http://www. corpwatch.org/article.php?id=3129.

Nelson J (2001) Cooperation between the United Nations and All Relevant Partners, in Particular the Private Sector' in Report of the Secretary General, A 56/323. New York: United Nations.

Potoski M \& Prakash A (2005) Green clubs and voluntary governance: ISO14001 and firms' regulatory compliance. American Journal of Political Science, 49 (2):235-248.

Risse T (2000) Let's argue! Communicative action in international relations. International Organization, $54: 1-39$.

Ruggie JG (2002) The theory and practice of learning networks: Corporate social responsibility and the global compact. Journal of Corporate Citizenship, 5:27-36.

Ruggie JG (2003) Taking Embedded Liberalism Global: The Corporate Connection. In: D Held \& M Koenig-Archibugi (eds). Taming Globalization: Frontiers of Governance. Cambridge: Polity Press.

Sutopo AH \& Arief A (2010) Terampil Mengolah Data Kualitatif dengan NVIVO. Jakarta: Prenada Media Group.

Tamm H \& Snidal D (2014) Rational Choice and Principal-Agent Theory. In: T Weiss \& R Wilkinson (eds). International Organization an Global Governance. London: Routledge.s

Tesner S (2000) The United Nations and Business. A Partnership Recovered. New York: St Martin’s Press.

Therien JP \& Pouliot V (2006) The global compact: Shifting the politics of international development?. Global Governance, 12 (1):55-75.

Williams OF (2004) The UN Global Compact: The challenge and the promise. Business Ethics Quarterly, 14 (4):755-774.

Zurn M (2000) Democratic governance beyond the nation state: The EU and other International Institutions. European Journal of International Relations, 6 (2):183-221. 